\title{
Evaluation of site amplification factors for shallow rock sites of Islamabad, Pakistan.
}

\author{
Shamsher Sadiq ${ }^{1,2}$, Muhammad Aaqib ${ }^{2}$, Saeed-ullah J. Mandokhail ${ }^{3, *}$, Maqsood-Ur-Rehman ${ }^{4}$, \\ Alam Mehtab ${ }^{5}$, Naik Muhammad ${ }^{3},{\text { Muhammad B. } \text { Adeel }^{2}}^{2}$ \\ ${ }^{1}$ GIK Institute of Engineering Sciences and Technology, Topi, Pakistan \\ ${ }^{2}$ Hanyang University, Seoul, South Korea \\ ${ }^{3}$ BUITEMS, Quetta, Blouchistan, Pakistan \\ ${ }^{4}$ NESPAK, Lahore, Punjab, Pakistan \\ ${ }^{5}$ Institute of Mountain Hazards and Environment, Chengdu, China \\ *Corresponding author: saeed_mandokhail@yahoo.com
}

\begin{abstract}
Current seismic provisions in Building Code of Pakistan (BCP-2007), seismic site classifications, and corresponding site amplification factors were determined similar to Uniform Building Code (UBC-1997), which were based on the local site conditions of Western United States with low impedance contrast, deep sites, and high seismicity conditions. The use of these deep sites based amplification factors to the shallow sites may not be appropriate to capture shallow sites' response. In this study, we performed a non-linear site-specific response analysis suite to compute the amplification factors for the six (06) representative shallow bedrock sites of Islamabad, Pakistan. The computed amplification factors are compared with BCP-2007 code-based design estimates; it is found that BCP-2007 code-based guidelines underestimate amplification factors at a short period whereas overestimating at an extended period. The study's findings highlight the potential implications of current code-based amplification factors for Islamabad's shallow sites and suggest improving the current seismic guidelines.
\end{abstract}

Keywords: BCP, 2007; natural period; response spectra; shear wave velocity; site response analysis (SRA).

\section{Introduction}

Pakistan's location is such that it lies in a zone with collision expression among the Indian and Eurasian plates (Farah et al., 1984). Islamabad is the capital of Pakistan, and it lies right at the edge of the Potohar Plateau. Islamabad, the capital of Pakistan, is surrounded by several active faults, making it prone to earthquakes. Some of these faults are the Jhelum fault, Rawat fault, Kalabagh fault, and the Main Mantle Thrust (MMT) (Mahmood et al., 2015; Sadiq et al., 2018), as shown in figure 1 . One of the most destructive earthquakes that hit Pakistan in the recent past was the 8th October 2005 earthquake, with the epicenter, about $100 \mathrm{~km}$ north-northeast from Islamabad killed about 87,350 people all over Pakistan (Naeem et al., 2005; Raghukanth, 2008). Figure 2 elaborated the Margalla tower Islamabad, which also collapsed during this earthquake (Shoukat et al., 2015b). In seismically active regions like the Western US, Taiwan, Japan, a large magnitude earthquake are more 


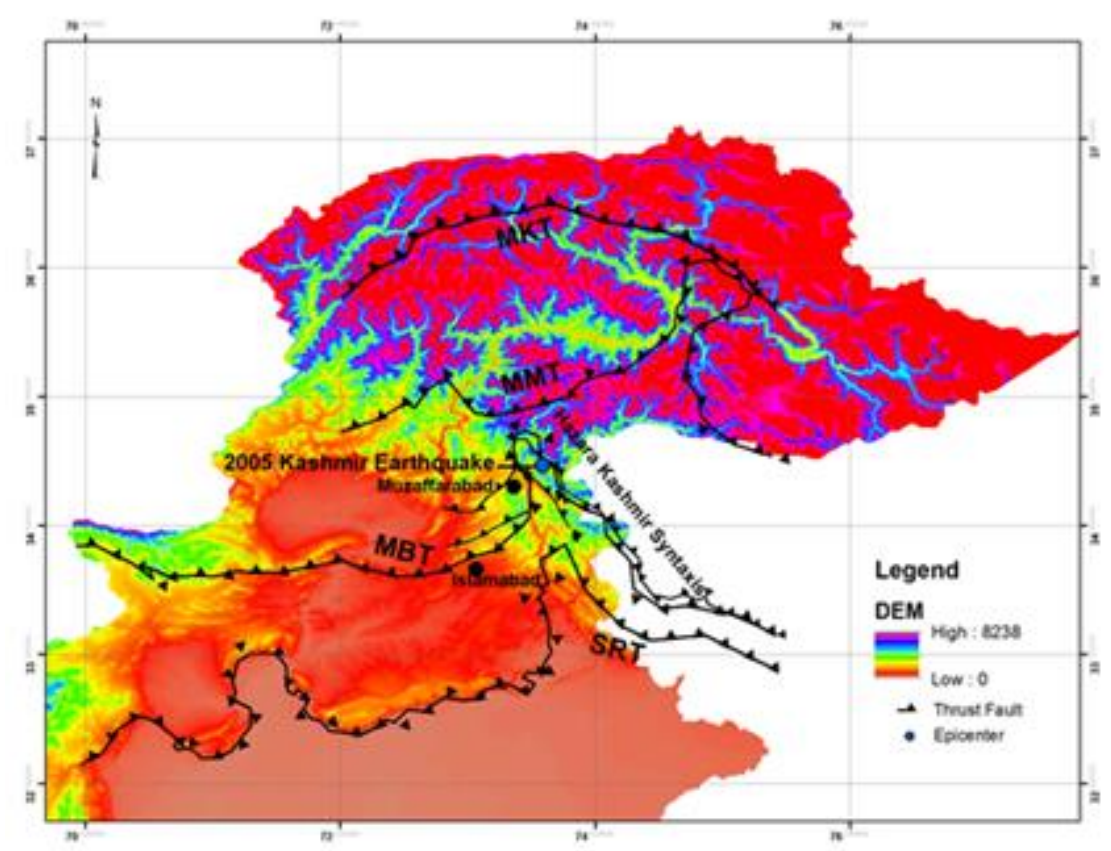

Fig. 1. Map showing major fault systems around Islamabad and Kashmir Earthquake, 2005 epicenter location (Mahmood et al., 2015; Sadiq et al., 2018)
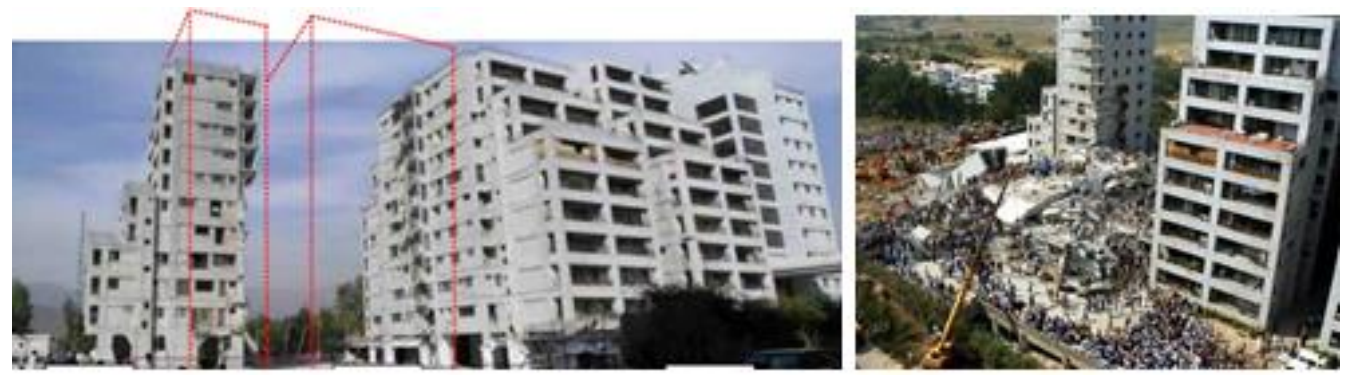

Fig. 2. Margalla tower collapse in the 8th October 2005 earthquake (Shoukat et al., 2015a)

frequent, but it is very seldom that the death toll rate crosses double figures. This is due to the improved site-specific seismic building codes in these countries.

Various studies have been published emphasizing the need for site-specific amplification evaluation for the shallow bedrock regions. The variation in the amplification of the ground motion depends on the geotechnical characteristics of the region. Kim \& Yoon, 2006, proposed a new site classification system based on bedrock depth and average shear wave velocity of soil for Korea's shallow rock sites and proposed a new set of amplification factors (AF) corresponding to the proposed site classification system. Anbazhagan et al., 2012, concluded that the site amplification factors implemented in China's seismic design codes, India and Australia, represent stiffer site conditions because of the shallow nature of soil profiles in the region. Aaqib M, 2018, presented site-specific AF while emphasizing the need for strength correction in site response analysis. Pehlivan et al., 2017, presented site-specific AF for Korea and concluded that it underestimates the design spectrum at short periods and 
overestimates at long periods. (Muhammad et al., 2018; Pehlivan et al., 2017; Sun et al., 2018) discussed the importance of the sitespecific non-linear $\mathrm{AF}$ and the potential implications of observed differences on the design building code practices for the shallow bedrock regions.

Few studies on the site-specific amplification characteristics of Pakistan have also been published. Mahmood et al., 2016, used four ground motions and performed a $1 \mathrm{D}$ equivalent linear site response analysis to study the site-specific amplification characteristics that lead to the collapse of Margalla tower in Islamabad during 2005 Muzaffarabad earthquake. Mahmood et al., 2019, performed a 1D non-linear site-specific response analysis using seven ground motions to study the Peshawar district of Pakistan's amplification characteristics. However, in these studies, site-specific amplification spectra were not developed, and hence no comparison was made with the seismic provisions in the building code of Pakistan (BCP, 2007). Also, in the above studies, very few ground motions were used to account for the variability of the ground motions' frequency characteristics. Also, the studies mentioned above have not highlighted the shallow nature of the bedrock encountered in the region. Since site amplification is directly related to local site conditions, using site factors derived from the recorded earthquake that occurred in different ground conditions may mislead the estimated seismic response. Therefore, it is essential to investigate the amplification factors considering Islamabad's local site conditions, Pakistan.

This study presents the site-specific amplification characteristics of Islamabad, Pakistan. A suite of 1D non-linear site response analysis was performed to estimate the AF by utilizing Islamabad's local site conditions, Pakistan. Six representative sites from Islamabad were selected. The newly developed amplification factors and response spectra are also compared with seismic codebased design estimates (BCP, 2007).

\section{Review of seismic provisions of building code of Pakistan (BCP, 2007)}

Current seismic provisions in the Building Code of Pakistan (BCP, 2007) presented in Chapter 5, Section IV has been adopted from Chapter 16, Division II of Uniform Building Code (UBC, 1997). There has been no update made to these mandatory seismic provisions in practice since 2007. Building Code of Pakistan (BCP, 2007) defines the seismic demand in terms of ground motion compatible with design response spectra. The required inputs for defining the design response spectra are listed below;

i. Figure 3 represents five (05) seismic zone for Pakistan based on the Probabilistic Seismic Hazard Analysis (PSHA). Based on the building's location, it is required to find the site's seismic zone using Figure 3.

ii. Compute the seismic zone factor, $\mathrm{Z}$, from Table 1. $\mathrm{Z}$ represents the mapped Peak Ground Acceleration (PGA) having a $10 \%$ probability of exceedance in 50 years (475 years' annual return period).

iii. The site is classified based on top $30 \mathrm{~m}$ average shear wave velocity, Standard Penetration Tests (SPT) blow count (N), or undrained shear strength, as given in Table 2. This Classification is identical to Uniform Building Code (UBC, 1997).

iv. Site amplification factors termed seismic coefficients, $\mathrm{C}_{\mathrm{a}}$ (short period amplification factor), and $\mathrm{Cv}$ (long period amplification factor) are $\mathrm{Z}$ and site class functions. Table 3 and Table 4 presents the short and long period amplification factors, respectively. These seismic factors are identical to Uniform Building Code (UBC, 1997).

v. The Building Code of Pakistan (BCP 2007) defined and presented in Figure 4 that the Building Code's design response 


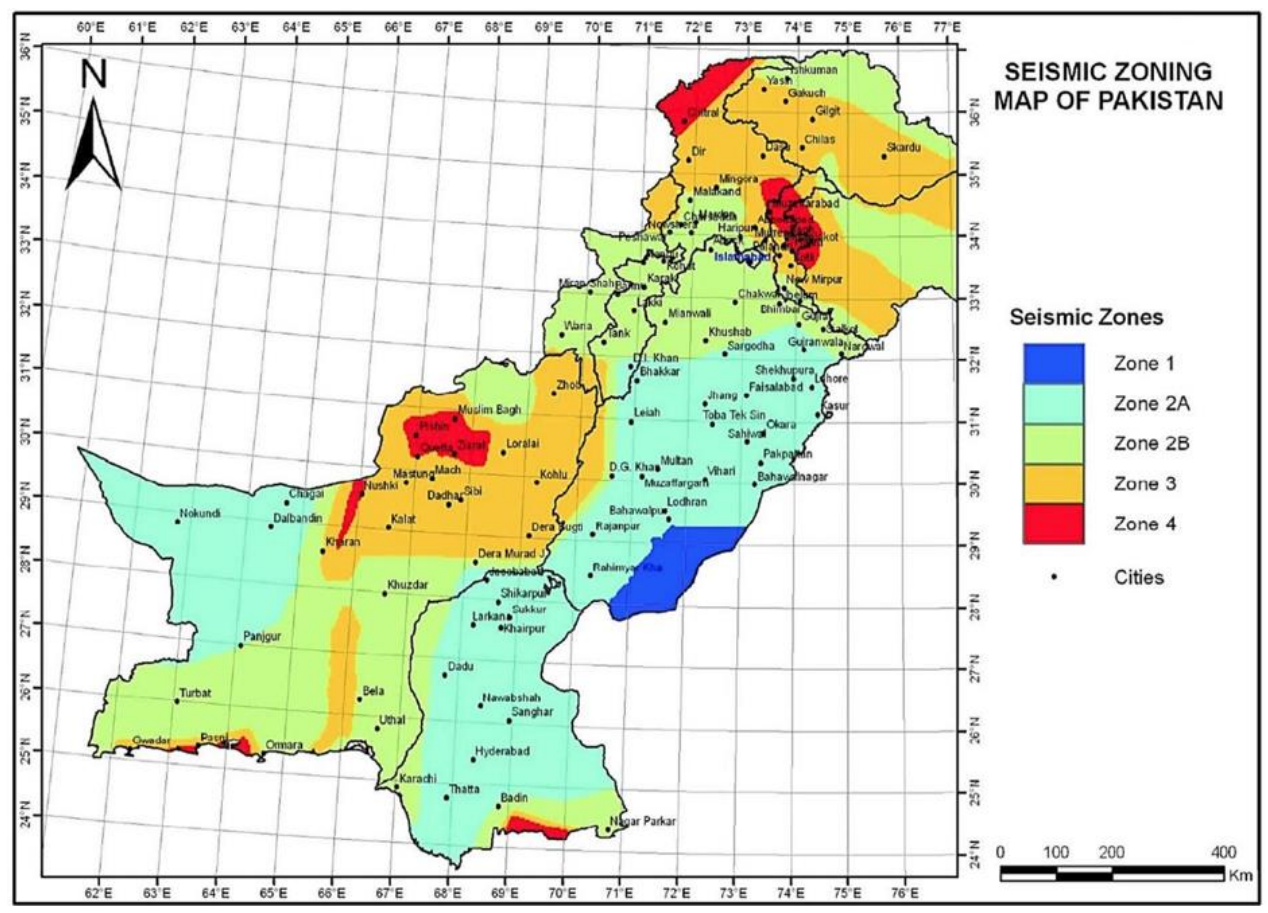

Fig. 3. Seismic zonation based on seismic hazard analysis (BCP, 2007).

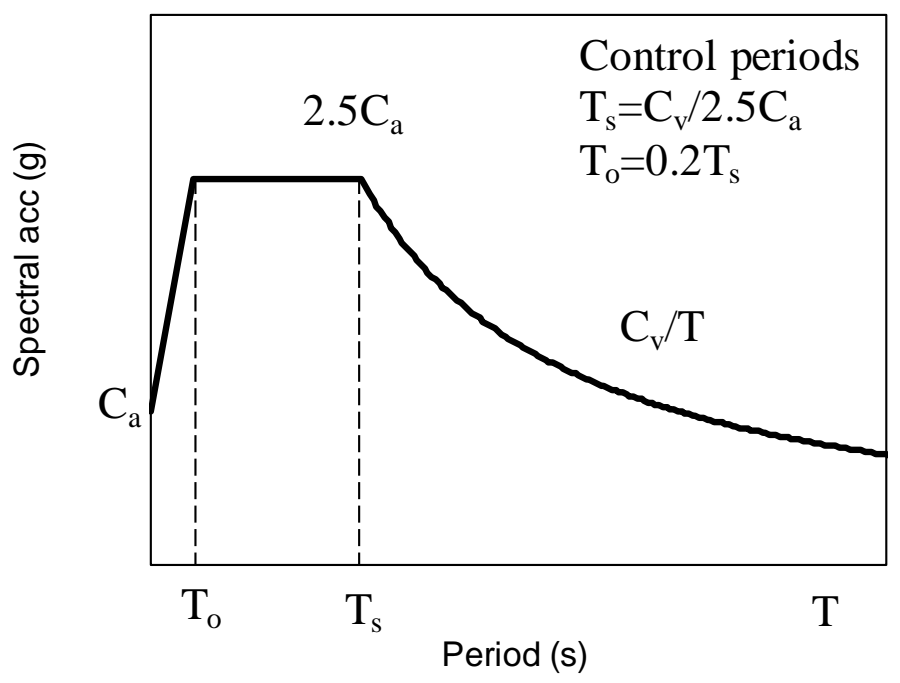

Fig. 4. Definition of design response spectra (BCP, 2007) 
Table 1. Seismic zone factor, Z (BCP, 2007)

\begin{tabular}{cccccc}
\hline Zone & $\mathbf{1}$ & $\mathbf{2 A}$ & $\mathbf{2 B}$ & $\mathbf{3}$ & $\mathbf{4}$ \\
\hline $\mathrm{Z}$ & 0.075 & 0.15 & 0.2 & 0.3 & 0.4 \\
\hline
\end{tabular}

Table 2. Seismic soil profile types (BCP, 2007)

\begin{tabular}{|c|c|c|c|c|}
\hline \multirow[b]{2}{*}{ Site } & \multirow[b]{2}{*}{ Description } & \multicolumn{3}{|c|}{ Average properties of top $30 \mathrm{~m}$ soil profile } \\
\hline & & $\begin{array}{l}\text { Shear wave velocity, } V_{s} \\
(\mathrm{~m} / \mathrm{s})\end{array}$ & $\begin{array}{l}\text { Standard Penetration } \\
\text { Test, blow count, } \mathbf{N}\end{array}$ & $\begin{array}{c}\text { Undrained shear strength, } \\
\text { Su } \\
(\mathbf{k P a}) \\
\end{array}$ \\
\hline $\mathrm{S}_{\mathrm{A}}$ & Hard rock & $>1500$ & - & - \\
\hline $\mathrm{S}_{\mathrm{B}}$ & Rock & $750-1500$ & - & - \\
\hline $\mathrm{S}_{\mathrm{C}}$ & $\begin{array}{l}\text { Very dense } \\
\text { soil/Soft rock }\end{array}$ & $360-760$ & $>50$ & $>100$ \\
\hline $\mathrm{S}_{\mathrm{D}}$ & Stiff soil & $175-350$ & $15-50$ & $50-100$ \\
\hline $\mathrm{S}_{\mathrm{E}}$ & Soft soil & $<175$ & $<15$ & $<50$ \\
\hline $\mathrm{S}_{\mathrm{F}}$ & \multicolumn{4}{|c|}{ Soil require site-specific evaluation } \\
\hline
\end{tabular}

Table 3. Seismic coefficients $\mathrm{C}_{\mathrm{a}}(\mathrm{BCP}, 2007)$

\begin{tabular}{cccccc}
\hline \multirow{2}{*}{ Site } & \multicolumn{5}{c}{ Seismic Zone Factor, $\mathbf{Z}$} \\
\cline { 2 - 6 } & $\mathbf{Z = 0 . 0 7 5}$ & $\mathbf{Z = 0 . 1 5}$ & $\mathbf{Z = 0 . 2}$ & $\mathbf{Z = 0 . 3}$ & $\mathbf{Z}=\mathbf{0 . 4}$ \\
\hline $\mathrm{S}_{\mathrm{A}}$ & 0.06 & 0.12 & 0.16 & 0.24 & $0.32 \mathrm{~N}_{\mathrm{a}}$ \\
$\mathrm{S}_{\mathrm{B}}$ & 0.08 & 0.15 & 0.20 & 0.30 & $0.40 \mathrm{~N}_{\mathrm{a}}$ \\
$\mathrm{S}_{\mathrm{C}}$ & 0.09 & 0.18 & 0.24 & 0.33 & $0.40 \mathrm{~N}_{\mathrm{a}}$ \\
$\mathrm{S}_{\mathrm{D}}$ & 0.12 & 0.22 & 0.28 & 0.36 & $0.44 \mathrm{~N}_{\mathrm{a}}$ \\
$\mathrm{S}_{\mathrm{E}}$ & 0.19 & 0.30 & 0.34 & 0.36 & $0.36 \mathrm{~N}_{\mathrm{a}}$ \\
$\mathrm{S}_{\mathrm{F}}$ & & \multicolumn{5}{c}{ Site-specific response analysis } \\
\hline
\end{tabular}

Table 4. Seismic coefficients $C_{v}$ (BCP, 2007)

\begin{tabular}{cccccc}
\hline \multirow{2}{*}{ Site } & \multicolumn{5}{c}{ Seismic Zone Factor, $\mathbf{Z}$} \\
\cline { 2 - 6 } & $\mathbf{Z = 0 . 0 7 5}$ & $\mathbf{Z = 0 . 1 5}$ & $\mathbf{Z = 0 . 2}$ & $\mathbf{Z = 0 . 3}$ & $\mathbf{Z = 0 . 4}$ \\
\hline $\mathrm{S}_{\mathrm{A}}$ & 0.06 & 0.12 & 0.16 & 0.24 & $0.32 \mathrm{~N}_{\mathrm{v}}$ \\
$\mathrm{S}_{\mathrm{B}}$ & 0.08 & 0.15 & 0.20 & 0.30 & $0.40 \mathrm{~N}_{\mathrm{v}}$ \\
$\mathrm{S}_{\mathrm{C}}$ & 0.03 & 0.25 & 0.32 & 0.45 & $0.56 \mathrm{~N}_{\mathrm{v}}$ \\
$\mathrm{S}_{\mathrm{D}}$ & 0.18 & 0.32 & 0.40 & 0.54 & $0.64 \mathrm{~N}_{\mathrm{v}}$ \\
$\mathrm{S}_{\mathrm{E}}$ & 0.26 & 0.50 & 0.64 & 0.84 & $0.96 \mathrm{~N}_{\mathrm{v}}$ \\
$\mathrm{S}_{\mathrm{F}}$ & \multicolumn{5}{c}{ Site-specific response analysis } \\
\hline \multicolumn{5}{c}{}
\end{tabular}

spectra are similar to the Uniform Building Code (UBC, 1997).

\section{Site response analysis}

\subsection{Site Characterization}

In this study, the data of Standard Penetration Test (SPT) collected by Sadiq et al., 2019, was used. The data was compiled from 130 different project sites consists of 445 boreholes from the area enclosed by the yellow dotted line shown in Figure 5. Borehole data was plotted in GIS software, and geo-spatial zonation was developed using the Kriging tool. Based on depth to bedrock and soil layer thickness, six representative soil profiles were selected, as shown in Figure 6 and summarized in Table 5. 


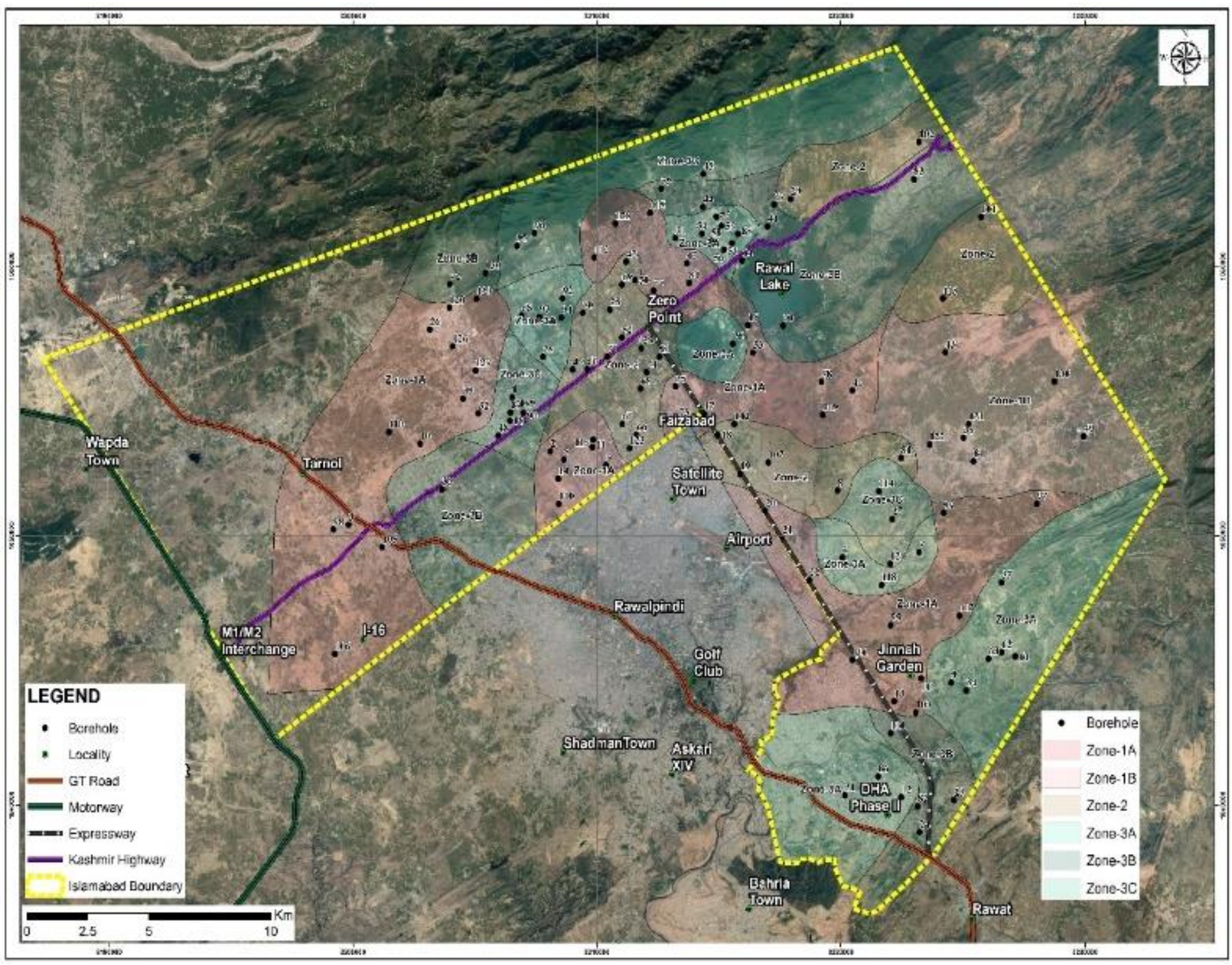

Fig. 5. Map of Islamabad, location of in-situ boreholes.
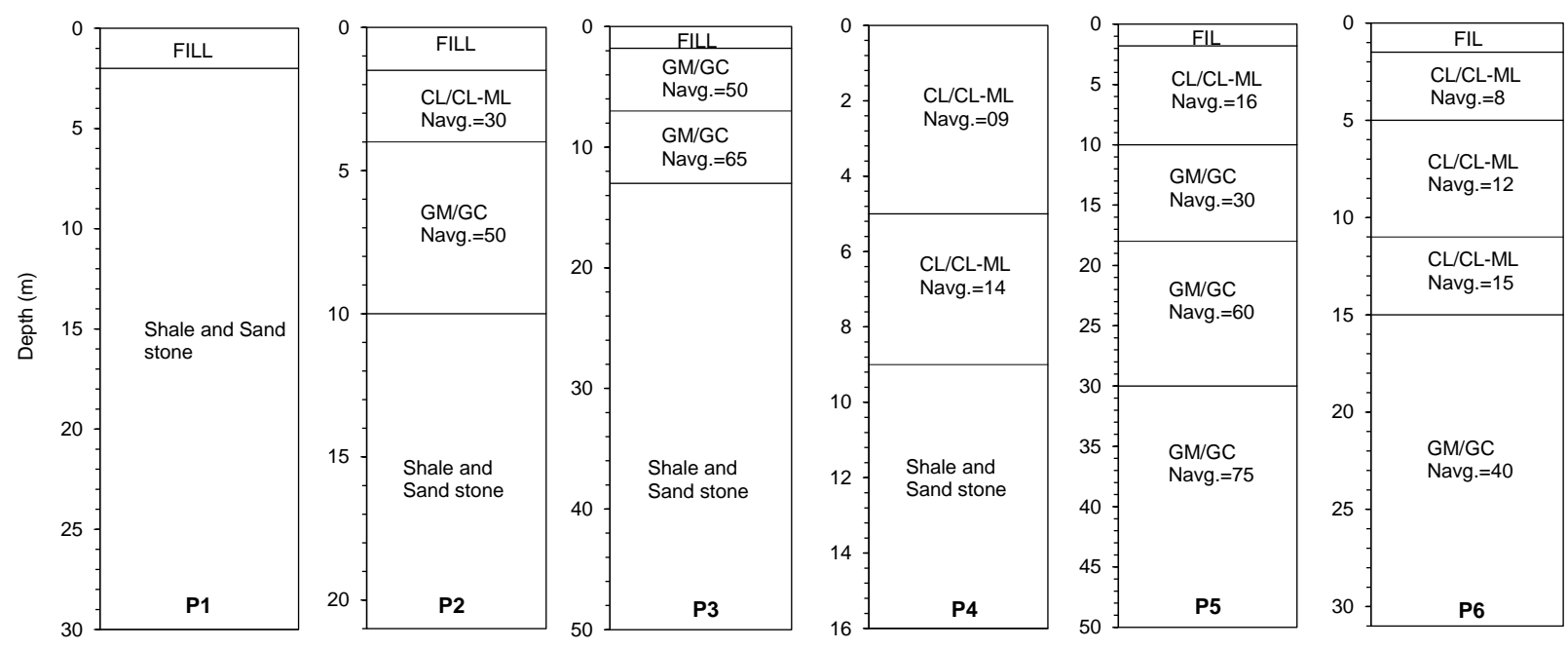

Fig. 6. Soil profiles with stratigraphy and SPT-N blow count.

Several researchers have proposed correlations between SPT-N values and shear wave velocity, Vs. Mahmood et al., 2015, proposed and discussed that Lee's, 1990, correlation provides Vs. Profile very close to the average Vs. Value of the representative profile for Islamabad. In this study, we also used the correlation proposed by Lee, 1990, 
to obtain the shear wave velocity profiles from the SPT-N values.

The depth of the bedrock was measured from the borehole reports. All the profiles compiled in this study have shallow bedrock depths ranging from $2 \mathrm{~m}$ to $50 \mathrm{~m}$. For simplicity, the shear wave velocity and unit weight of the bedrock was assumed to be 780 $\mathrm{m} / \mathrm{s}$ and $22 \mathrm{kN} / \mathrm{m}^{3}$, respectively, as recommended by Mahmood et al., 2015. The developed shear wave velocity profiles of the six representative sites used in the study are shown in

Fig. 77 Time-weighted average shear wave velocity of top $30 \mathrm{~m}\left(\mathrm{~V}_{\mathrm{s} 30}\right)$ was calculated by Eq. (1)

$$
V_{s 30}=\frac{30}{\sum_{i=1}^{30} \frac{d i}{V s i}}
$$

The time-averaged velocity of soil $\left(\mathrm{V}_{s ., \text { soil }}\right)$ deposits above the bedrock were calculated by Equation (2).

$V_{s, \text { soil }}=\frac{\sum_{i=1}^{n} d i}{\sum_{i=1}^{n} \frac{d i}{V s i}}$

The natural period of the soil profile $\left(\mathrm{T}_{\mathrm{G}}\right)$ corresponds to the fundamental frequency of the profile was calculated by Equation (3).

$$
T_{G}=4 \sum_{i=1}^{n} \frac{d i}{V s i}
$$

The characteristics of selected representative soil profiles are summarized in Table 6.

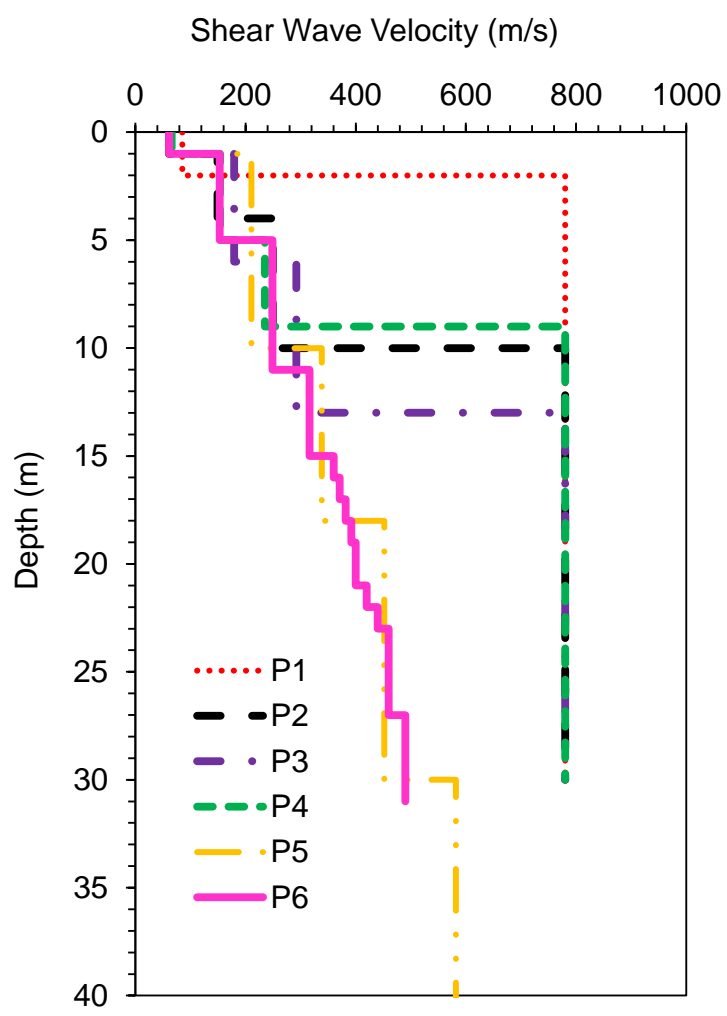

Fig. 7. Developed shear wave velocity profiles.

Table 5. Selection of six representative soil profiles for Islamabad based on geo-spatial plotted borehole database shown in Figure 5.

\begin{tabular}{cccc}
\hline $\begin{array}{c}\text { Geo-spatial } \\
\text { zone }\end{array}$ & Profile name & $\begin{array}{c}\text { Thickness of soil layer } \\
(\mathbf{m})\end{array}$ & No. of boreholes \\
\hline Zone-1A & P1 & 02 & 86 \\
Zone-1B & P2 & 10 & 35 \\
Zone-02 & P3 & 12 & 80 \\
Zone-3A & P4 & 09 & 85 \\
Zone-3B & P5 & 50 & 102 \\
Zone-3C & P6 & 31 & 57 \\
\hline
\end{tabular}


Table 6. Summary of the selected site profiles.

\begin{tabular}{cccccc}
\hline Site & $\begin{array}{c}\text { Site Class } \\
(\mathbf{B C P}, \mathbf{2 0 0 7})\end{array}$ & $\begin{array}{c}\mathbf{V}_{\mathbf{s 3 0}} \\
(\mathbf{m} / \mathbf{s})\end{array}$ & $\begin{array}{c}\mathbf{V}_{\mathbf{s}, \text { soil }} \\
(\mathbf{m} / \mathbf{s})\end{array}$ & $\begin{array}{c}\text { Site Period } \\
\mathbf{T}_{\mathbf{G}},(\mathbf{s})\end{array}$ & $\begin{array}{c}\text { Depth to bed } \\
\text { rock }(\mathbf{m})\end{array}$ \\
\hline P1 & $\mathrm{S}_{\mathrm{C}}$ & 600 & 142 & 0.056 & 02 \\
P2 & $\mathrm{S}_{\mathrm{C}}$ & 522 & 315 & 0.127 & 10 \\
P3 & $\mathrm{S}_{\mathrm{C}}$ & 512 & 353 & 0.147 & 12 \\
P4 & $\mathrm{S}_{\mathrm{C}}$ & 465 & 240 & 0.150 & 09 \\
P5 & $\mathrm{S}_{\mathrm{D}}$ & 319 & 357 & 0.560 & 50 \\
P6 & $\mathrm{S}_{\mathrm{D}}$ & 282 & 284 & 0.437 & 31 \\
\hline
\end{tabular}

\subsection{Input ground motions}

The ground motion that is considered as an input for the design of civil engineering structures is the main unknown of this analysis. In Pakistan, there are only a few records that can be used for dynamic analysis. Therefore, recorded acceleration time histories as input motion is a better alternative and appealing in the site response analysis. Due to the shallow bedrock nature of Islamabad sites, NGA (Next Generation Attenuation)-west 2 database recorded ground motions were used as input ground motions in this study. NGA-West2 ground motion database includes recorded ground motions of shallow crustal earthquakes (https://ngawest2.berkeley.edu/) (Ancheta $e t$ al., 2014). To account for the wide range of frequency content of earthquake ground motions, nine recorded input motions were selected having moment magnitudes $\left(\mathrm{M}_{\mathrm{w}}\right)$ ranging from 5.6 to 6.9 , rupture distances between $9.6 \mathrm{~km}$ and $40.4 \mathrm{~km}$, and PGA ranging from $0.1 \mathrm{~g}$ to $0.41 \mathrm{~g}$, as shown Figure 8 and summarized in Table 7. The selected motions were scaled to $0.2 \mathrm{~g}$ following the procedure outlined in ASCE 7-10 (Charney, 2015).

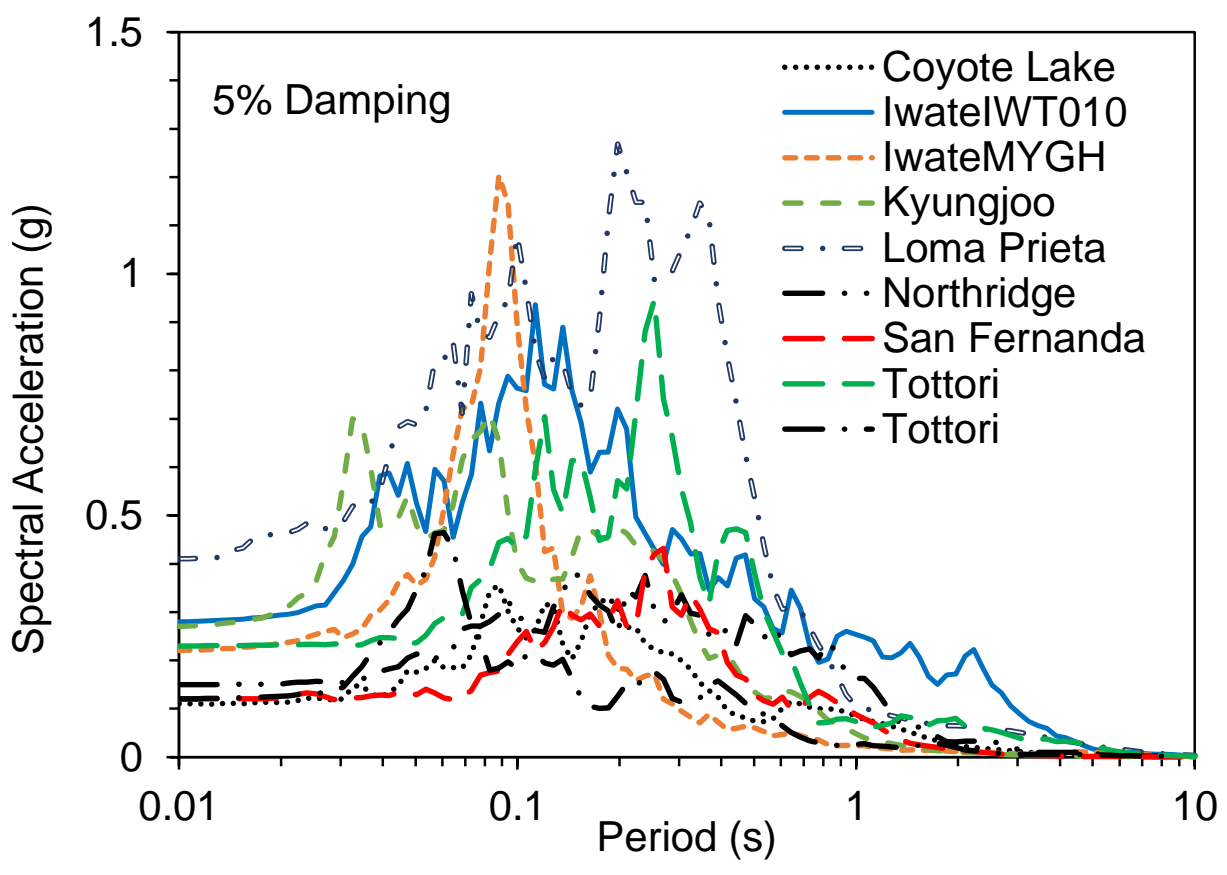

Fig. 8. Response spectra of selected rock outcrop motions. 
Table 7. Input ground motion characteristics.

\begin{tabular}{|c|c|c|c|c|c|c|c|c|}
\hline $\begin{array}{l}\text { S. } \\
\text { No }\end{array}$ & $\begin{array}{c}\text { Earthquake } \\
\text { Name }\end{array}$ & Year & $\begin{array}{l}\text { Station } \\
\text { Name }\end{array}$ & $\begin{array}{c}\text { Magnitude, } \\
\text { Mw }\end{array}$ & Fault & $\begin{array}{c}\text { Rupture } \\
\text { distance, } \\
\text { Rrup } \\
\text { (km) }\end{array}$ & $\begin{array}{l}V_{S 30} \\
(\mathbf{m} / \mathbf{s})\end{array}$ & $\begin{array}{c}\text { PGA } \\
\text { (g) }\end{array}$ \\
\hline 1 & Loma Prieta & 1989 & $\begin{array}{l}\text { Gilroy } \\
\text { Array } 1\end{array}$ & 6.9 & $\begin{array}{l}\text { Reverse } \\
\text { oblique }\end{array}$ & 9.6 & 1428 & 0.11 \\
\hline 2 & Northridge & 1994 & $\begin{array}{l}\text { LA- } \\
\text { Wonderland } \\
\text { Ave }\end{array}$ & 6.7 & $\begin{array}{l}\text { Reverse } \\
\text { oblique }\end{array}$ & 20.3 & 1222 & 0.28 \\
\hline 3 & Coyote Lake & 1979 & $\begin{array}{l}\text { Gilroy } \\
\text { Array } 1\end{array}$ & 5.7 & $\begin{array}{l}\text { Strike } \\
\text { slip }\end{array}$ & 10.7 & 1428 & 0.22 \\
\hline 4 & Tottori & 2000 & SMNH 10 & 6.6 & $\begin{array}{l}\text { Strike } \\
\text { slip }\end{array}$ & 15.6 & 967 & 0.41 \\
\hline 5 & Iwate & 2008 & IWT010 & 6.9 & Reverse & 16.3 & 825 & 0.15 \\
\hline 6 & San Fernanda & 1971 & Pasadenaold & 6.6 & Reverse & 21.5 & 969 & 0.12 \\
\hline 7 & Tottori & 2000 & OKYH07 & 6.6 & $\begin{array}{l}\text { Strike } \\
\text { slip }\end{array}$ & 15.2 & 940 & 0.09 \\
\hline 8 & Iwate & 2008 & MYGH04 & 6.9 & Reverse & 40.4 & 849 & 0.23 \\
\hline 9 & Kyungjoo Korea & 2016 & MKL & 5.8 & $\begin{array}{l}\text { Strike } \\
\text { slip }\end{array}$ & 13.0 & & 0.12 \\
\hline
\end{tabular}

\subsection{Numerical modeling}

1D analysis has been proven through extensive case studies to provide a reliable estimate of surface response. Non-linear site response analysis on the selected representative soil profiles was performed using the program DEEPSOIL v6.1 (Hashash et al., 2016). The Modified Kondner-Zelasko (MKZ) model (Matasović \& Vucetic, 1993) was used for the non-linear analyses. The shear modulus ratio $\left(\mathrm{G} / \mathrm{G}_{\max }\right)$ and damping ratio (D) curves were defined using the discrete points model at various confining pressures. Due to the unavailability of sitespecific dynamic curves and index properties, widely used modulus reduction and damping curves of Darendeli (Darendeli, 2001) were adopted with over-consolidation ratio (OCR) being assumed as 1 , the horizontal at-rest earth pressure factor $\left(\mathrm{K}_{0}\right)$ as 0.5 , plasticity index (PI) as zero (0), and the number of cycles of loading $(\mathrm{N})$ and the excitation frequency (f) are defined as 10 and 1, respectively. The modulus reduction and damping curve fitting procedure, termed MRDF, matched the non-linear target curves (Phillips \& Hashash, 2009). The small strain damping was modeled with the Rayleigh damping formulation. The $1^{\text {st }}$ and $5^{\text {th }}$ modes were selected to reduce the frequencydependent damping, as Kwok et al., 2007, recommended. The bedrock was modeled as an elastic half-space because the selected input motions were recorded as rock outcrop motions. The non-linear site response analysis for all the six profiles was performed with the 9 input motions shown in Figure 8.

\section{Results and discussions}

For each rock outcrop input motion, surface acceleration response spectra and associated $\mathrm{AF}$ at each period were calculated for the six representative profiles. Figure 9 a \& b represents the computed surface acceleration 
spectra and the computed amplification factors for profile P3. The bold red line represents the average acceleration spectra and AF in Figure 9. Maximum amplification was observed at the natural site period $\mathrm{T}_{\mathrm{G}}$, as shown in Figure 9. a. The short-period amplification coefficient $\left(\mathrm{F}_{\mathrm{a}}\right)$ and long period amplification coefficient $\left(\mathrm{F}_{\mathrm{v}}\right)$ were calculated within the integration intervals of $0.1-0.5 \mathrm{~s}$ and 0.4-2.0s, respectively, as specified in the National Earthquake Hazard Reduction Program (NEHRP) provisions (Borcherdt, 1996; Dobry et al., 2000). The computed average AF at each period of the six sites is presented in Fig. 10. It is observed that amplification at short periods, i.e., $F_{a}$ is higher than at a more extended period, i.e., $\mathrm{F}_{\mathrm{v}}$ for all the profiles, which agrees with the previous studies for the shallow bedrock sites (Kim \& Yoon, 2006; Pehlivan et al., 2017). One reason for a low computed $F_{v}$ value could be that the profiles are shallow, and there is minimal amplification beyond $1.5 \mathrm{~s}$, while in our study, the long period coefficient was calculated for an integration interval of up to 2.0s, which is according to the Building Code of Pakistan (BCP, 2007). Several previous studies (Kim \& Yoon, 2006) have suggested adjusting the long period amplification $\left(F_{v}\right)$ integration interval for shallow bedrock sites.
Comparison of code-design spectrum BCP, 2007, and current study design spectrum for site class $C$ and $D$ are shown in Figure 11 and Figure 12, respectively. The comparison shows that the code-based spectrum significantly predicts the response at period range $0.01>\mathrm{T}>0.4 \mathrm{~s}$ whereas overpredict for the period range $\mathrm{T}>0.4 \mathrm{~s}$ for both site classes $\mathrm{C}$ and $\mathrm{D}$. This can be explained by the fact that the code is generalized on deep sites, which might not be applicable, as depicted in the current study.

All the profiles used in this study have low site periods, leading to a high short period amplification.

The comparison of computed non-linear AF with those of code-based are summarized in Table 8 and Table 9. Short period AF, $F_{a}$ was underestimated, whereas the long period amplification factors, $F_{v}$, were overestimated in the seismic provision of BCP, 2007. The percentage difference calculated by Equation (4) of short-period amplification was up to $29.4 \%$ for site class C, with P4 showing the most considerable difference, while it was up to $25.13 \%$ for site class D P6 showing the most considerable difference. Similarly, the overestimation of long period amplification was up to $32.5 \%$ for site class $\mathrm{C}$, with $\mathrm{P} 1$ showing the most considerable difference,
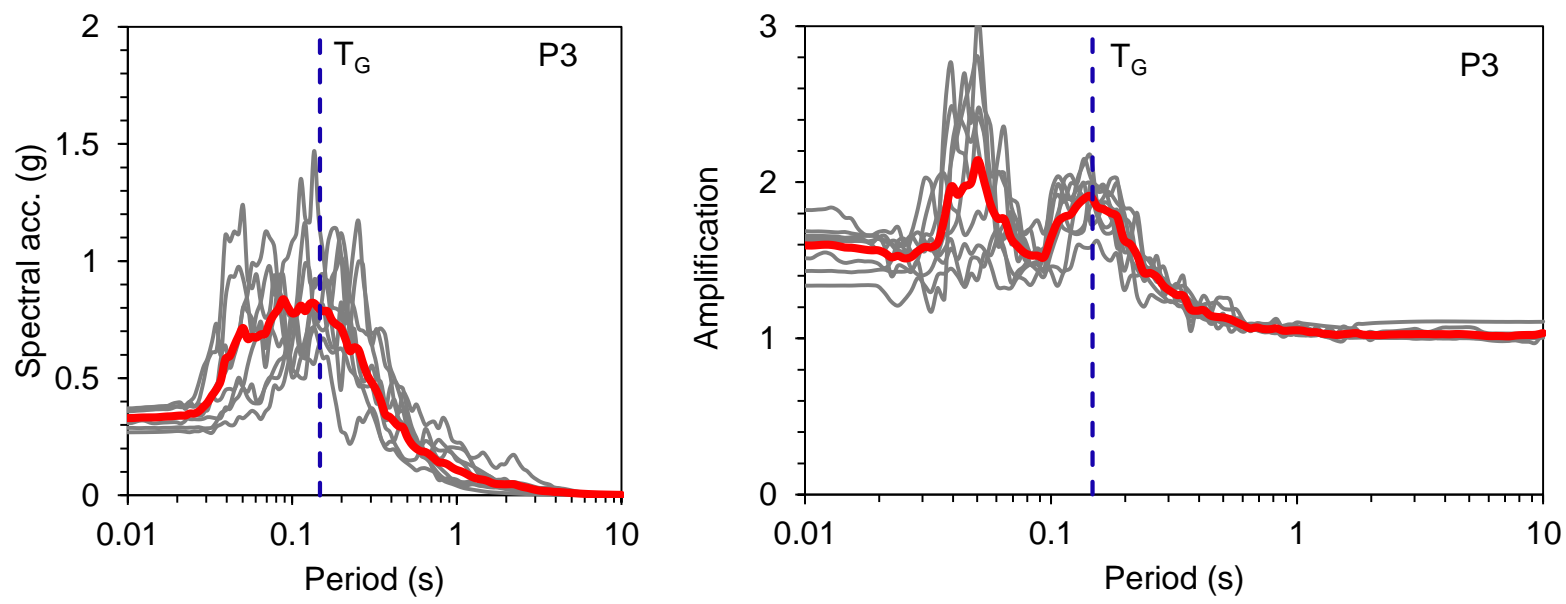

Fig. 9. Profile P3 a) Computed surface response spectra b) Computed non-linear AF factors. 
while it was up to $41 \%$ for site class D, with P5 showing the most considerable difference. The AF's for both short periods

$$
\text { Percentage difference }=\frac{\text { BCP factor-this study }}{\text { BCP factor }} \times 100
$$
and long periods increase with an increase in $\mathrm{T}_{\mathrm{G}}$.
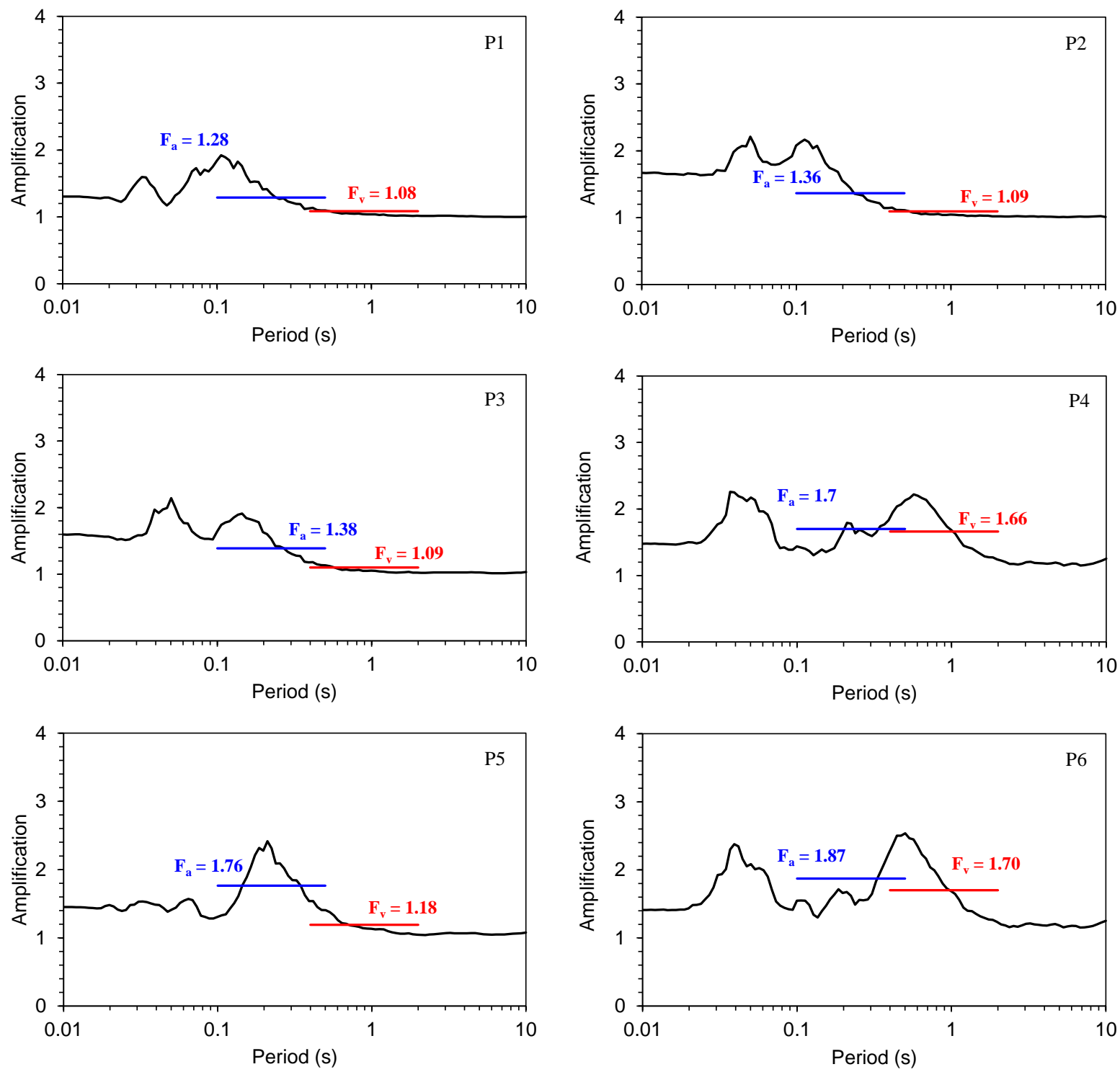

Fig. 10. Calculated site AFs for short and long periods. 


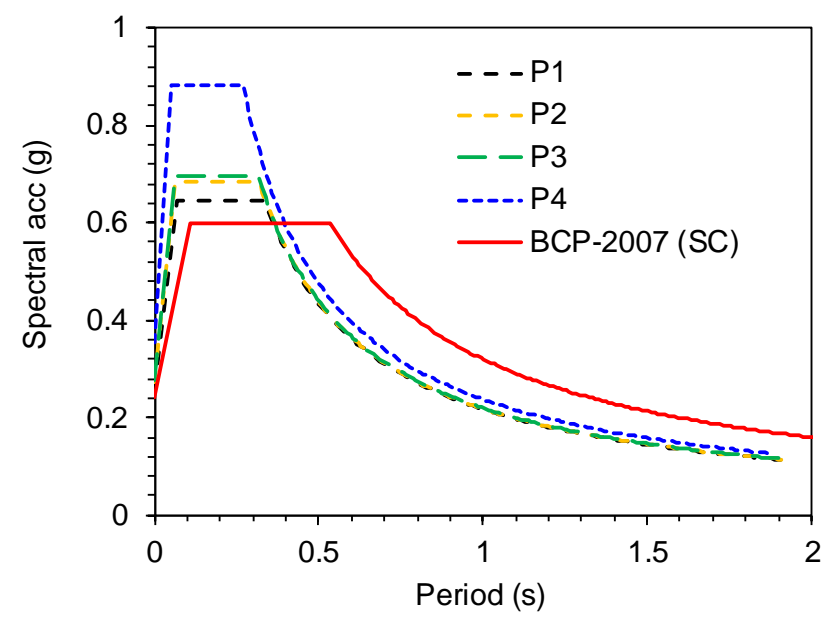

Fig. 11. Comparison of code-design BCP-2007 and current study design spectrum for site class C.

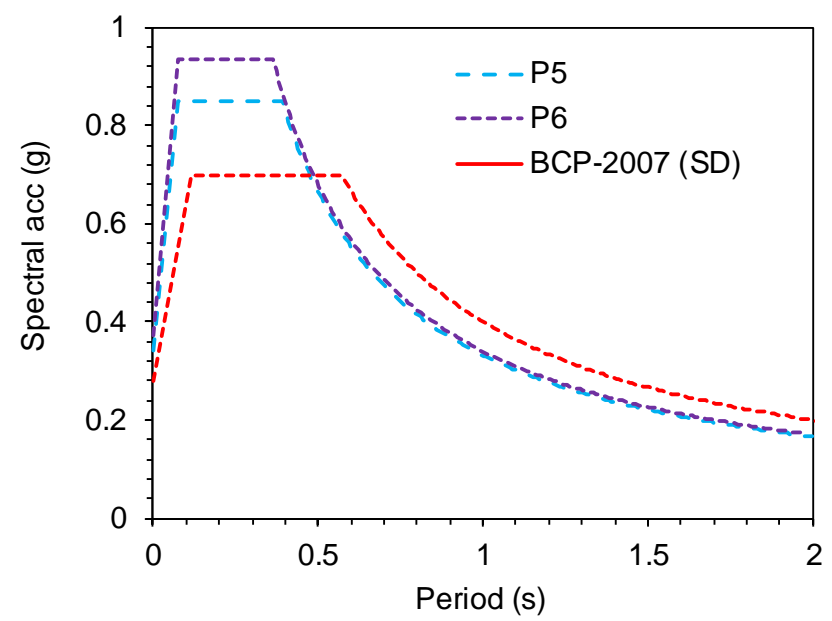

Fig. 12. Comparison of code-design BCP-2007 and current study design spectrum for site class D.

Table 8. Comparison of short-period amplification factor.

\begin{tabular}{|c|c|c|c|c|c|}
\hline \multirow[b]{2}{*}{ Profile } & \multirow[b]{2}{*}{ Seismic zone } & \multirow{2}{*}{$\begin{array}{c}\text { Site } \\
\text { Category }\end{array}$} & \multicolumn{3}{|c|}{ Short-period coefficients } \\
\hline & & & $\begin{array}{l}\text { This } \\
\text { study }\end{array}$ & $\begin{array}{c}\text { BCP } \\
(2007) \\
\end{array}$ & $\begin{array}{c}\text { Percentage } \\
\text { difference }\end{array}$ \\
\hline $\mathrm{P} 1$ & \multirow{6}{*}{ Zone-2B } & \multirow{4}{*}{$\mathrm{S}_{\mathrm{C}}$} & 1.28 & \multirow{4}{*}{1.2} & -6.70 \\
\hline $\mathrm{P} 2$ & & & 1.36 & & -13.3 \\
\hline P3 & & & 1.38 & & -15.0 \\
\hline P4 & & & 1.7 & & -29.40 \\
\hline P5 & & \multirow[b]{2}{*}{$\mathrm{S}_{\mathrm{D}}$} & 1.76 & \multirow{2}{*}{1.4} & -25.70 \\
\hline P6 & & & 1.87 & & -25.13 \\
\hline
\end{tabular}


Table 9. Comparison of long period amplification factor.

\begin{tabular}{|c|c|c|c|c|c|}
\hline \multirow[b]{2}{*}{ Profile } & \multirow[b]{2}{*}{ Seismic zone } & \multirow{2}{*}{$\begin{array}{c}\text { Site } \\
\text { Category }\end{array}$} & \multicolumn{3}{|c|}{ Short-period coefficients } \\
\hline & & & $\begin{array}{c}\text { This } \\
\text { study }\end{array}$ & $\begin{array}{c}\text { BCP } \\
(2007)\end{array}$ & $\begin{array}{l}\text { Percentage } \\
\text { difference }\end{array}$ \\
\hline $\mathrm{P} 1$ & \multirow{6}{*}{ Zone-2B } & \multirow{4}{*}{$\mathrm{S}_{\mathrm{C}}$} & 1.08 & \multirow{4}{*}{1.6} & +32.5 \\
\hline $\mathrm{P} 2$ & & & 1.09 & & +31.9 \\
\hline P3 & & & 1.09 & & +31.9 \\
\hline P4 & & & 1.66 & & +-3.75 \\
\hline P5 & & \multirow{2}{*}{$\mathrm{S}_{\mathrm{D}}$} & 1.18 & \multirow{2}{*}{2} & +41.0 \\
\hline P6 & & & 1.70 & & +15.0 \\
\hline
\end{tabular}

\section{Conclusions and recommendation}

This study presents the amplification factors for the shallow sites of Islamabad, Pakistan. Surface responses were computed by performing the numerical simulations using 1D-site response analysis software DEEPSOIL with non-linear MKZ constitutive model calibrated by generalized non-linear soil properties of Darendeli, 2001 for the six representative soil profiles with shallow bedrock from Islamabad.

Following conclusions were drawn from the study reported in this paper.

1. The short-period amplification was higher than the extended period due to shallow bedrock and high impedance contrast. The AF's for both short periods and long periods increase with an increase in $\mathrm{T}_{\mathrm{G}}$.

2. The comparison of observed site $\mathrm{AF}$ at the short and long period with the Building Code of Pakistan (BCP, 2007) shown that the short period amplification was underestimated whereas long period amplification was overestimated, which can be attributed to the Building Code of Pakistan (BCP, 2007) being based on deep sites.

3. There might be a need to adjust the integration interval for an extended period of amplification because there is no significant amplification beyond the periods of 1.0 or $1.5 \mathrm{~s}$ in the case of the shallow sites.

4. The presented amplification factors for Islamabad's representative sites highlight the need to revise the Building Code of Pakistan (BCP, 2007) and develop a new site classification system and site amplification factors that account for the shallow bedrock effect. For the site conditions similar to the current study's representative sites, the presented amplification factors may be used to develop the design spectrum for the design of new building structures in Islamabad; otherwise, it is recommended to perform site-specific response analysis 


\section{References}

Aaqib M. SS; D. Park.; YM.A Hashash. \& M. Pehlivan. (2018) Importance of Implied Strength Correction for 1D Site Response at Shallow Sites at a Moderate to Low Seismicity Region. In: Geotechnical Earthquake Engineering and Soil Dynamics V. DOI:doi:10.1061/9780784481462.043

Anbazhagan P; Sheikh MN; Parihar A. (2012) Influence of rock depth on seismic site classification for shallow bedrock regions. Natural Hazards Review 14 (2):108-121.

Ancheta TD; Darragh RB; Stewart JP; Seyhan E; Silva WJ. et al. (2014) NGAWest2 database. 30 (3):989-1005.

BCP. (2007) Building Code of Pakistan 2007, Ministry of Housing \& Works, Government of Pakistan.

Borcherdt RD Strong ground motions generated by the Northridge and HanshinAwaji earthquakes of 17th January (1994) and (1995); Implications for site-specific design factors. In: Eleventh World Conference on Earthquake Engineering, Procs. (1996).

Charney FA Seismic Loads: Guide to the Seismic Load Provisions of ASCE 7-10. In, (2015). American Society of Civil Engineers,

Darendeli MB. (2001) Development of a new family of normalized modulus reduction and material damping curves. The University of Texas at Austin (UTA).

Dobry R; Borcherdt R; Crouse C; Idriss I; Joyner W. et al. (2000) New site coefficients and site classification system used in recent building seismic code provisions. Earthquake spectra 16 (1):41-67.

Farah A; Abbas G; De Jong KA; Lawrence RD. (1984) Evolution of the lithosphere in Pakistan. Tectonophysics 105 (1-4):207-227.

Hashash YMA; Musgrove MI; Harmon JA; Okan, I; Groholski DR. et al. (2016) DEEPSOIL, User Manual. 6.1.

Kim D-S; Yoon J-K. (2006) Development of a new site classification system for the regions of shallow bedrock in Korea. Journal of Earthquake Engineering 10 (03):331-358.

Kwok AO; Stewart JP; Hashash YMA; Matasovic N; Pyke R. et al. (2007) Use of exact solutions of wave propagation problems to guide implementation of nonlinear seismic ground response analysis procedures. Journal of Geotechnical and Geoenvironmental Engineering $\mathbf{1 3 3}$ (11):1385-1398.

Lee SHHJJotCIoE. (1990) Regression models of shear wave velocities in Taipei basin. 13 (5):519-532.

Mahmood I; Qureshi SN; Tariq S; Atique L; Iqbal MFJPc. (2015) Analysis of landslides triggered by October 2005 Kashmir earthquake. 7.

Mahmood K; Farooq K; Memon SAJJoAG. (2016) One-dimensional equivalent linear ground response analysisA case study of collapsed Margalla Tower in Islamabad during 2005 Muzaffarabad Earthquake. 130:110-117.

Mahmood K; Iqbal Q; Khan H. (2019) One Dimensional Non-Linear Ground Response Analysis-A Site-Specific Case Study of Peshawar District, Pakistan. Technical Journal 24 (02).

Matasović N; Vucetic MJJoGE. (1993) Cyclic characterization of liquefiable sands. 119 (11):1805-1822.

Muhammad A; Shamsher S; Duhee P; Youssef H; Menzer P. (2018) Importance of 
Implied Strength Correction for 1D Site Response at Shallow Sites at a Moderate to Low Seismicity Region. In: Geotechnical Earthquake Engineering and Soil Dynamics V. DOI:doi:10.1061/9780784481462.043

Naeem A; Ali Q; Javed M; Hussain Z; Naseer A. et al. (2005) First report on the Kashmir earthquake of 8th October 2005. EERI Special Earthquake Report.

Pehlivan M; Duhee P; Shamsher S; Hashash Y; Seismic site response of shallow sites in moderate seismicity regions. In: Proceedings of the 19th International Conference on Soil Mechanics and Geotechnical Engineering, Seoul, Korea. (2017).

Phillips C; Hashash YMA. (2009) Damping formulation for non-linear 1D site response analyses. Soil Dynamics and Earthquake Engineering, 29 (7):1143-1158.

Raghukanth S. (2008) Ground motion estimation during the Kashmir earthquake of 8th October 2005. Natural Hazards 46 (1):113.

Sadiq S; Khan U; Alam M; Mandokhail SJ; Ahmed. (2018) NZ, Ikram A Numerical Evaluation of Slope Stability measures: A Case Study of Birham Landslide, Murree, Pakistan. In: IOP Conference Series: Materials Science and Engineering. Vol 1. IOP Publishing, p 012028.
Sadiq S; Mandokhail SJ; Muhammed A. (2019) Development of Islamabad Community Geotechnical site database. (Unpublished).

Shoukat S; Rehman Z; Mahmood K; Ashraf M. (2015a) Geotechnical Site Evaluation of Collapsed Margalla Tower in Islamabad due to October 2005 Muzzafarabad Earthquake. University of Engineering and Technology Taxila Technical Journal 20 (3):117.

Shoukat S; Rehman Z; Mahmood K; Ashraf MJUoE; Journal TTT. (2015b) Geotechnical Site Evaluation of Collapsed Margalla Tower Islamabad due to October 2005 Muzzafarabad Earthquake. 20 (3):117.

Sun C-G; Kim H-S; Cho H-I. (2018) GeoProxy-Based Site Classification for Regional Zonation of Seismic Site Effects in South Korea. Applied Sciences 8 (2):314.

UBC Uniform building code. In: International Conference of Building Officials, Whittier, CA. (1997).

Submitted: 01/05/2019

Revised : 18/03/2020

Accepted : 24/03/2020

DOI $\quad: 10.48129 / \mathrm{kjsv} 48 \mathrm{i} 2.7772$ 